\title{
УДК 811.161.2:004738.5
}

\section{Коневщинська Ольга Еммануїлівна}

кандидат педагогічних наук, старший науковий співробітник, вчений секретар

Інститут інформаційних технологій і засобів навчання НАПН України, м. Київ, Україна

ORCID 0000-0003-4125-8764

ok17188vk@ukr.net

\section{ПРОБЛЕМА ІНТЕРНЕТ-МОВЛЕННЯ СТАРШОКЛАСНИКІВ В ЕЛЕКТРОННИХ СОЦІАЛЬНИХ МЕРЕЖАХ}

\begin{abstract}
Анотація. У статті досліджено проблему Інтернет-мовлення старшокласників під час міжособистісної комунікації в електронних соціальних мережах. Обгрунтовано актуальність, здійснено системний аналіз психолого-педагогічної і навчально-методичної літератури з проблеми дослідження. Розглянуто зовнішнє писемне Інтернет-мовлення як важливий чинник комунікаційної культури особистості. Визначено, що Інтернет-мовлення $\epsilon$ мовленнєвою діяльністю особистості у мережі Інтернет із використанням Інтернет-мови. Доведено, що високий рівень Інтернет-мовлення як учнів, так і вчителів у процесі міжособистісній комунікації в електронних соціальних мережах є важливими аспектами підвищення рівня медіакультури, медіаінформаційної компетентності особистості та необхідними вимогами інформаційного суспільства для здійснення ефективної проектноорієнтованої, навчально-пізнавальної та інноваційної діяльності в освітній практиці.
\end{abstract}

Ключові слова: Інтернет-мовлення, соціальні мережі; міжособистісна комунікація.

\section{1. ВСТУП}

\section{Постановка проблеми}

Найбільш глибокі й радикальні зміни у сучасному суспільстві пов'язані 3 розширенням можливостей сучасних медіа й Інтернет технологій для здійснення мережної комунікації. Безперечним виявляється той факт, що комунікація присутня в усіх сферах інформаційного суспільства. Вивчаючи наукові джерела [1-12], розуміємо, що комунікація є багатоаспектним об'єктом дослідження багатьох наукових напрямів: соціологічного, кібернетичного, політологічного, філософського, психологічного, лінгвістичного, культурологічного, освітнього. Вона $є$ необхідною передумовою функціонування і розвитку різних соціальних систем, що забезпечує зв'язок між людьми, робить можливим накопичення і передачу соціального досвіду, трансляцію культури й освіти сучасними IКТ [1]. Досліджуючи феномен соціальних мереж у сучасному суспільстві, вітчизняні дослідники цілком виправдано співставляють їх із засобами масової комунікації, і зазначають, що електронна комунікація у мережі серед багатьох інших, $є$ важливим компонентом педагогічної системи у відкритому інформаційно-освітньому середовищі. У структурі цього феномену поєднуються такі елементи як: міжособистісна мережна комунікація, інформаційна потреба, полікультурна спрямованість, багатомовність та специфічність Інтернет-мови, інформаційна насиченість, інтерактивність, швидкість, доступність інформації для здійснення взаємодії з освітньою метою.

Звужуючи коло нашого наукового пошуку відповідно до мети дослідження, вважаємо актуальним розгляд мовно-лінгвістичного аспекту цього складного явища, а саме, проблеми Інтернет-мови, яку старшокласники застосовують в процесі міжособистісної комунікації в електронних соціальних мережах.

Аналіз останніх досліджень і публікацій. Для більш глибокого розуміння досліджуваної проблеми було здійснено аналіз науково-педагогічних джерел щодо 
визначення сутності понять комунікації, спілкування, взаємодії як основної передумови людського існування або соціальної діяльності за допомогою символів. У своїх роботах вітчизняні вчені Денисюк С. Г. [1], Баришполець О. Т. [2], Дмитренко Є. В. [3] досліджували сутність поняття комунікації, їі види, класифікацію; Шульська Н. М., Матвійчук Н. М. [4] розкрили доцільність використання соціальних мереж як ефективного середовища для викладацько-студентського спілкування; Каптюрова В.В. [8], [9] аналізувала лінгвістичний аспект Інтернет мовлення, вивчала новостворені лексичні одиниці (сленгізми), які використовуються комунікантами в соціальних мережах. Комунікативний аспект соціальних мереж у сучасному суспільстві досліджено у роботі Лещенко О., Немеш О. [10] проаналізувала вплив спілкування в соціальних мережах на розвиток особистості підлітка. Проблеми формування інформаційно-освітнього середовища навчання старшокласників на основі технологій електронних соціальних мереж досліджували Литвинова С. Г., Пінчук О. П., Буров О. Ю. та ін.. Процес розвитку медіаінформаційної компетентності учителів у сучасному інформаційному суспільстві досліджували Лещенко М. П, Тимчук Л. I, Овчарук О. В. [7]. Структурно-змістовий та функціонально-технічний аналіз веб-сайтів інтернет конференцій, специфіку Інтернет-мовлення представлено у роботах Вінарієвої А., Галичкіної С., Данилюк С., Чемеркіна С. [11]. Маковецька-Гудзь Ю. у роботі[12] зазначає, що фахівці у сучасному мовознавстві мають широкий простір для дослідження Інтернет-мови як нового лінгвістичного напряму. Низка науковців Соколов А., Войскунський А., Почепцов Г., Бацевич Ф., Бєлова А., Гаспаров Б., Карасик В. зосередили увагу на дослідженні проблем медіа-лінгвістики. Серед закордонних дослідників, які досліджують різні аспекти електронних соціальних мереж виділяють А. Бейвлас, С. Берковіц, П. Марсдеа, Дж. Морено, Б. Уеллман, Л. Фріман.

Мета статті полягає у дослідженні проблеми Інтернет-мовлення старшокласників у процесі міжособистісної комунікації в електронних соціальних мережах.

\section{2. МЕТОДИ ДОСЛІДЖЕННЯ}

Для проведення дослідження мовного аспекту електронних соціальних мереж, зокрема використання Інтернет мови для здійснення мовленнєвої діяльності (мовлення) старшокласниками у процесі міжособистісної комунікації, як частини науководослідної роботи, що виконується в Інституті інформаційних технологій і засобів навчання НАПН України було використано комплекс теоретичних та емпіричних методів, серед яких: системний аналіз психолого-педагогічної і навчально-методичної літератури з проблеми дослідження, опитування респондентів, узагальнення отриманих результатів.

\section{3. РЕЗУЛЬТАТИ ДОСЛІДЖЕННЯ}

Стрімкий стан розвитку Інтернет технологій, новітніх медіа засобів сприяє швидкій трансформації сучасної освіти, і потребує сформованих медіакультури, медіаосвіченості, медіаінформаційної грамотності, медіаобізнаності та мережної комунікаційної культури особистості для здійснення інноваційної діяльності в освітній галузі [1].

У вітчизняних науково-педагогічних колах серед науковців продовжується активна дискусія щодо поширення негативних тенденцій у мовленнєвій культурі учнівської молоді в процесі електронної комунікації засобами мережних технологій, зокрема електронних соціальних мереж (ЕСМ). 
Так, спираючись на дослідження вітчизняних науковців, безперечним $\epsilon$ твердження, що сучасна система електронної комунікації між учасниками інформаційно-освітнього середовища засобами мережних технологій поєднує два важливих аспекти - спілкування і взаємодію.

Боришполець О. Т. [2] зазначає, що частина науковців вважають синонімічними поняттями спілкування і взаємодія, інтерпретуючи їх як комунікацію або обмін інформацією, інші розглядають їх як відношення форми деякого процесу і його змісту. Також у наукових джерелах існує думка про самостійне існування спілкування як комунікації, і взаємодії як інтеракції. Інтерактивність - поняття, що розкриває характер і ступінь взаємодії між об'єктами, ця властивість стає основною ознакою комунікацій в інформаційному суспільстві [2].

У нашому дослідженні розглядаємо процес мовлення старшокласників у ЕСМ, як форму спілкування. Так, в Енциклопедії освіти АПН України [3] зазначено, що мовлення є не тільки процесом, а й результатом - мовленнєві тексти, усні й писемні, книги тощо. Залежно від виду мовленнєвої діяльності виділяють зовнішнє, внутрішнє, усне й писемне мовлення. Зовнішнє мовлення слугує меті спілкування, внутрішнє відіграє головну роль у процесах свідомості, мислення. Мовленнєве спілкування сприяє організації спільної діяльності людей, пізнанню один одного, а також є істотним фактором у формуванні й розвитку міжособистісних стосунків [3, с. 514].

Так, Інтернет-мова, у нашому розумінні, - це знакова система, яка є основним засобом людського спілкування в мережі Інтернет, що об'єднує писемну й усну іiі форми відповідно до впорядкованої сукупності іï структурних одиниць (слів, морфологічних форм, словосполучень). Інтернет-мовлення є мовленнєвою діяльністю особистості у мережі Інтернет із використанням Інтернет-мови, яка грунтується на загальноприйнятих орфоепічних, лексичних, граматичних, орфографічних нормах.

У контексті нашого дослідження розглянуто зовнішнє писемне Інтернет-мовлення як важливий чинник комунікаційної культури особистості. Здійснений у роботі [4] аналіз співвідношення загальної, комунікативної, інформаційної та медіакультури особистості виявив важливі актуальні проблеми для розгляду, що залишилися поза увагою науковців. Розгляд мовленнєвого аспекту соціальних мереж $є$ логічним продовження попередніх наукових пошуків автора.

Здійснений аналіз наукових джерел [1-11], дає підставу для твердження, що стрімке зростання популярності цифрових медіа, Інтернет-сервісів, ЕСМ, сприяє здійсненню ефективної освітньої діяльності, всебічному розвитку суб'єктів навчального процесу відповідно до їх індивідуальних потреб і вимог суспільства. Інтернет-простір став новим засобом соціалізації особистості, новою формою електронного спілкування та взаємодії.

Електронні соціальні мережі необхідно розглядати як сучасний засіб міжособистісної електронної комунікації. Наявність позитивних характеристик ЕСМ (зручність, велика інформативність, загальнодоступність, неформальність, психологічний комфорт тощо) сприяє формуванню ефективного середовища для здійснення успішної міжособової комунікації між учителями, учнями і батьками в процесі навчання і в позаурочний час, допомагає долати будь-які бар'єри в обмеженості доступу до навчання, робить його нестандартним і цікавим, створює сприятливий психологічний клімат для оволодіння знаннями [4]. Таку форму навчальної діяльності позитивно оцінюють самі старшокласники, які відзначають іiі як інтерактивну, безперервну, зручну та доступну до інформації, а серед позитивних особливостей спілкування з учителем у соціальній мережі виділяють: можливість додаткового консультування, неформальність, доступність, одночасність спілкування з іншими. 
Для вчителя, процес спілкування з учнями через соціальні мережі в навчальних цілях, змінює його соціальну роль, він стає помічником, наставником для суб'єктів навчально-виховного процесу. У роботі [5] зазначено, що вчитель як представник інформаційної спільноти стоїть перед альтернативою виконання нових особистих ролей, вибору варіантів поведінки в мережі й контролю за власними діями в ній. Важливими також є вміння, які розширюють межі компетентностей вчителя: участь у створенні мережної спільноти у процесі мережної комунікації, опанування вмінь грамотно вимовляти текст, що вимагає чіткості й правильної вимови, уміння реагувати на питання, проводити діалог, а також виробляти індивідуальний підхід, позбавляючись стереотипів і формалізованої поведінки; дотримання сфери приватності, робота над собою в постійно змінних умовах медіальної комунікації; опанування новими IКТ.

У загальному розумінні О. Немеш [6] характеризує міжособистісну культуру спілкування в соціальних мережах як результат Інтернет орієнтованої діяльності, яка визначає смислове бачення $\mathrm{i}$ сприйняття віртуальної реальності, виражає суб'єктивність індивідів як представників певних соціальних груп, межі їх бачення світу і самих себе. Акцентує увагу на тому, що у культурі віртуальної взаємодії спочатку задана можливість формування суб'єкта як регулюючого початку просторовочасового континууму.

Проте, здійснені останнім часом спостереження дають підстави стверджувати про масове зниження рівня культури Інтернет-мовлення під час міжособової комунікації підлітків у соціальних мережах [7], [8], [10], [11]. Нині все частіше у науковопедагогічних колах можна почути висновки вчителів-мовників щодо визначення мови Інтернет-спілкування як нового стилю писемного розмовного мовлення [7], [8].

Отже, спілкування в ЕСМ набуває ознак усного мовлення, що відбувається у письмовій формі. Йому притаманні спонтанність, економія та надлишковість мовних засобів. Фахівці відзначають стилістичну, орфографічну, синтаксично-пунктуаційну безграмотність, обмеженість словарного запасу учасників комунікації, засміченість мовлення запозиченими словами, сленгом, тому ми спостерігаємо значні зміни способу міжособистісної комунікації.

Відтак, постає питання про вплив учителя на культуру мовлення молоді під час спілкування в Інтернеті?

У [9] наведено результати соціологічного опитування з питань інтернет-мовлення старшокласників у процесі спілкування в соцмережах. Так, на українськомовних версіях відомих соціальних мереж (Twitter, Facebook) лише 7\% користувачів залишають повідомлення (новини, статуси) українською мовою, «суржиком» спілкуються від 11\% до 18\% користувачів. З'ясовано, що майже 85\% інформації російськомовна, і лише $14 \%$ україномовних відомостей.

Останнім часом дослідники все більше говорять про проникнення специфічної термінології, професійного сленгу до повсякденної мови спілкування. Спілкування 3 усної форми переміщується в Інтернет простір. Активними учасниками міжособистісної комунікації, стають учні, студенти, учителі, батьки. Комуніканти в ЕСМ звертаються у своїх повідомленнях до таких скорочень й абревіатур, використання яких $\epsilon$ характерним для всіх користувачів. У дослідження В. В. Каптюрової [8] проаналізовані приклади слів, які відображають особливості міжособистісного спілкування в соціальних мережах: LMS (англ. like my status), PC4PC (Picture comment for picture comment), LOL (laughing out loud), OMG (oh, my God), BFF (best friends forever) та ін..

У [8] проаналізовані зміни, які відбуваються останнім часом в інтерактивному мережевому мовленні сучасної молоді, зокрема значно поширилося запозичення слів 3 
англійської мови: пост, інтерфейс, копірайтер, драйвер та ін. Утворення нового слова відбувається за допомогою додавання українських афіксів до кореня англійського слова: дрінкнути, клікнути, хакнути, копіпаснути, гуглити та ін. відбуваються лексикосемантичні зміни без змін на морфемному рівні: сторінка (в Інтернеті), мило (е-мейл), мишка (пристрій комп'ютера). Частіше комунікантами використовується комп'ютерний сленг і нецензурна лексика (наприклад, юзер, ламер, корект).

На думку фахівців-лінгвістів найважливішим джерелом поповнення словника Інтернет-мови є словотвір. Зміни, що відбуваються у словотворенні пов'язані з тим, що в багатьох Інтернет-ресурсах кількість знаків обмежена, тому, щоб компенсувати цей недолік, мовці вдаються до скорочень. Раніше абревіатури утворювалися шляхом скорочення слів за заголовною літерою (наприклад, ЗНЗ, ВНЗ), то нині спостерігається поява нової тенденції: абревіатури утворюються на основі англійських речень, наприклад, CU (See You - до зустрічі), OOTQ (Out of the question - звичайно, немає питань) та ін.

Цікавим виявляється дослідження Каптюрової В. В. [8], у якому проаналізовано приклади повідомлень користувачів соціальних мереж із вживанням комунікантами стилістично зниженої лексики (сленгу). Його використання пояснюється такими факторами:

- неоднорідний соціальний статус користувачів мережі;

- анонімність спілкування, що створює сприятливі умови для зниження почуття відповідальності користувачів;

- подальше поширення тенденції до демократизації мовлення.

Ми погоджуємося $з$ висновками Каптюровою В. В. [9], яка вказує на причини виникнення явища Інтернет сленгу, що спричинив появу нових негативних тенденцій:

- мова соціальних мереж перетворилася з модної течії на новий стиль он-лайн спілкування і правопису на сайтах, блогах, чатах;

- наявність орфографічних помилок входить у звичку і стає причиною занепаду грамотності;

- мова мережі функціонує тепер не лише у віртуальному просторі, але й надходить 3 усіх сучасних цифрових медіа;

- через постійне вживання Інтернет-сленгу підростаюче покоління не відчуває різниці між ним і правильною, літературною українською мовою;

- звикання до вживання мови-суржику та сленгу в повсякденному спілкуванні.

Узагальнення результатів проведеного дослідження дає можливість окреслити шляхи вирішення розглянутих проблемних питань.

Наприклад, розглянемо досвід створеної у соцмережі Facebook групи «Медіашкола професора Ганни Онкович» (рис.1, 2).

На сторінках цієї освітньої спільноти розміщено значну кількість науковометодичних, психолого-педагогічних та практико-орієнтованих матеріалів, анонси запланованих заходів та результати їх проведення, звітні фотодайджести, представлено для громадського обговорення проекти державних документів тощо. Коло учасників цієї групи охоплює майже всі регіони України і представляє різні сфери освітньої галузі - від наукової установи і громадської організації до дитячого дошкільного навчального закладу. Відбувається постійна комунікаційна дія між учасниками групи на сторінках у Facebook. Така дія спрямована на досягнення взаєморозуміння 3 метою координації професійної діяльності, мовлення, життєвої позиції та висловлювань щодо ціннісних орієнтацій. 


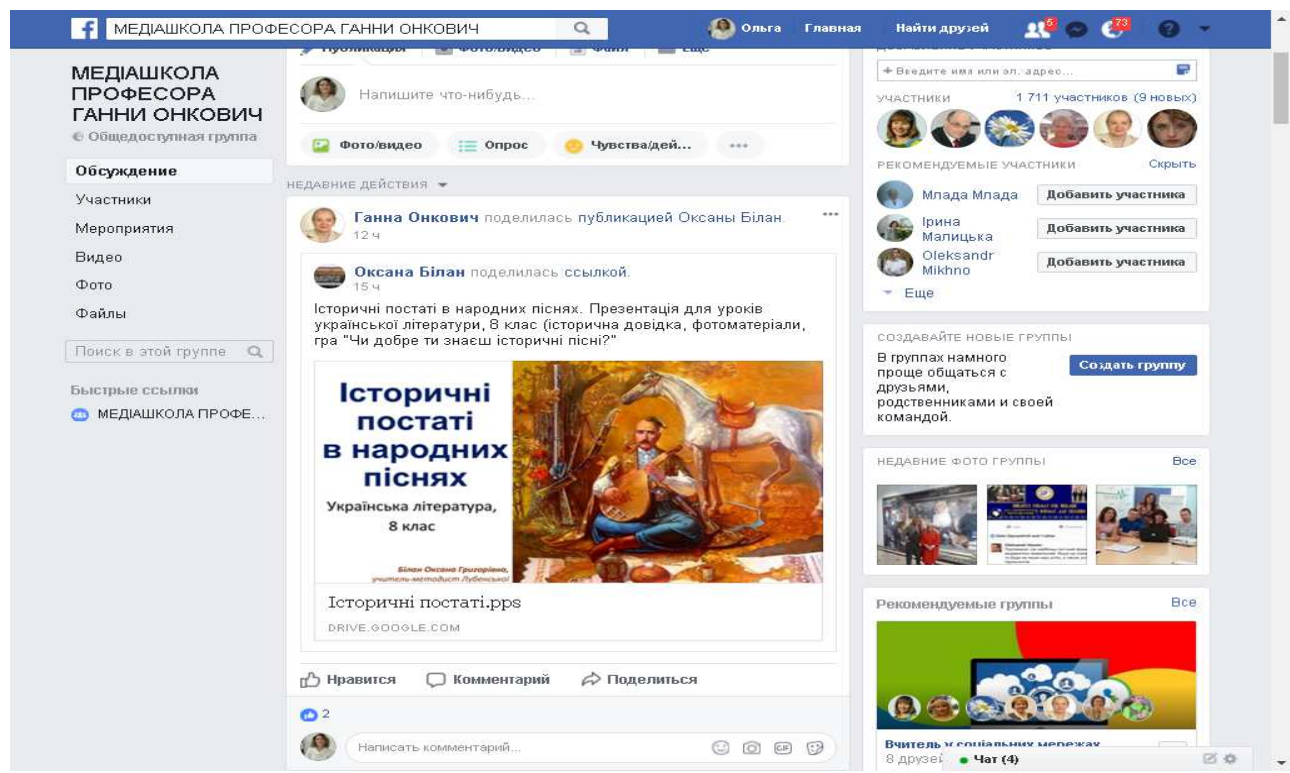

Рис. 1. Сторінка групи «Медіашкола професора Ганни Онкович» у соимережі Facebook

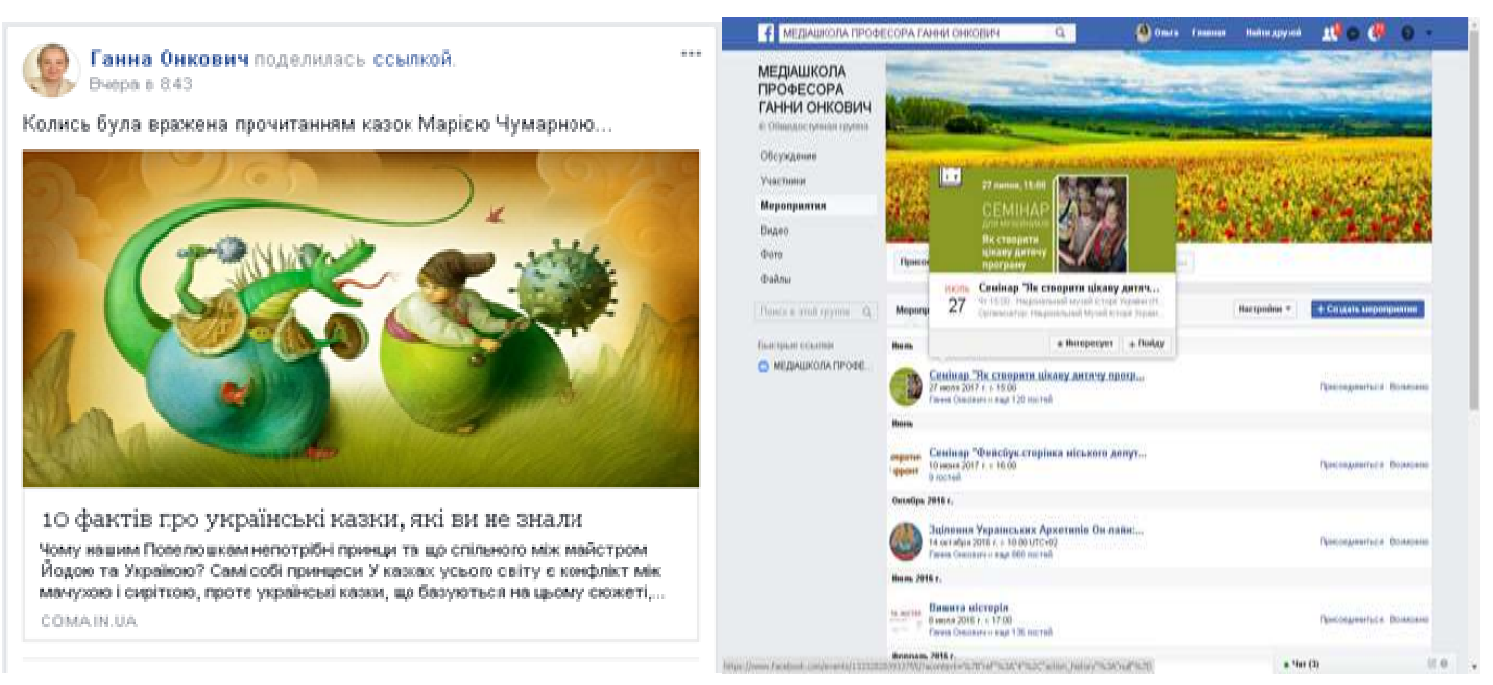

Рис. 2. Сторінки групи «Медіашкола професора Ганни Онкович» у сочмережі Facebook

У процесі Інтернет або мережної міжособистісної комунікації засобами ЕСМ між суб'єктами освітнього процесу відбувається обмін інформацією, виконуються різні дії 3 метою планування спільної діяльності. Це забезпечує взаємне стимулювання, контроль та взаємодопомогу в процесі розв'язання спільних проектів, а також сприяє більш ефективному їх виконанню.

Використання соціальних мереж як комунікаційного майданчика дозволяє організувати навчальну діяльність не тільки учнів, а й учителів. Як зазначають дослідники в роботі [10], що методично обгрунтоване та цілеспрямоване використання у навчальному процесі мережних сервісів має потужний потенціал для навчання та самовдосконалення учнів та підвищення IК компетентності вчителя. Застосування різних сервісів мережних технологій як сучасного освітнього інструментарію сприяє підвищенню якості навчального процесу, формуванню медіаінформаційної грамотності та ІК компетентності суб' єктів освітньої діяльності, що дозволяє швидко реагувати на нові вимоги інформаційного суспільства [5]. 
Отже, стрімкий розвиток Інтернет технологій у сучасному суспільстві спричиняє швидкі зміни Інтернет-мовлення користувачів, зокрема старшокласників, які відображають наявні проблеми зниження рівня ввічливості й поваги до співрозмовника, недотримання вимог етикету, невміння розрізняти жанрову, стилістичну доречність мовних засобів.

Зважаючи на сказане вище, ми дійшли висновку щодо необхідності посилення уваги з боку вчителя та батьків щодо підвищення рівня культури Інтернет-мовлення під час міжособистісної комунікації в Інтернет просторі, більш активного запровадження медіа освітніх практико-орієнтованих заходів (семінарів для вчителів, практикумів, факультативів, практичних занять з учнями) у загальноосвітніх навчальних закладах.

\section{4. ВИСНОВКИ ТА ПЕРСПЕКТИВИ ПОДАЛЬШИХ ДОСЛІДЖЕНЬ}

Узагальнення результатів проведеного дослідження дає підстави для формулювання висновків з окресленої проблеми.

Комунікацію в соціальних мережах розуміємо як складний, динамічний процес, який поєднує спілкування і взаємодію всіх учасників освітнього процесу.

Комунікацію як процес взаємодії можна розглядати у двох аспектах. По-перше, як контакт двох або більше осіб, що має своїм результатом взаємні зміни їх поведінки, діяльності тощо. По-друге, як взаємно зумовлені індивідуальні дії, що пов'язані 3 інформаційною потребою і причинною залежністю.

Міжособистісна комунікація у соціальних мережах - це унікальний засіб спілкування і взаємодії, що поєднує і реалізує потужні можливості мови та Інтернеттехнологій. Вона одночасно забезпечує функціонування вербальних, невербальних, формальних, неформальних, міжособистісних характеристик мовлення учасників навчально-виховного процесу.

Інтернет-мова, у нашому розумінні, - це знакова система, яка є основним засобом людського спілкування в мережі Інтернет, що об'єднує писемну й усну іï форми відповідно до упорядкованої сукупності іiї структурних одиниць (слів, морфологічних форм, словосполучень). Інтернет-мовлення $є$ мовленнєвою діяльністю особистості у мережі Інтернет із використанням Інтернет-мови, яка грунтується на загальноприйнятих орфоепічних, лексичних, граматичних, орфографічних нормах.

У контексті нашого дослідження розглянуто зовнішнє писемне Інтернет-мовлення як важливий чинник комунікаційної культури особистості.

Інтернет-мовлення $є$ універсальним засобом міжособистісної комунікації засобами соціальних мереж, оскільки при передачі інформації за допомогою мови менш за все втрачається сенс повідомлення. Проте, усе частіше спостерігається наявність семантичного бар'єру у міжособистісній комунікації, що включає проблеми вживання сленгу, обмеженого лексикону, та інші соціально-культурні, національнорелігійні, професійні особливості спілкування співрозмовників.

Аналізуючи відповіді учнівської молоді вважаємо, що підвищення мотивації до якісного опанування мови в процесі міжособистісної комунікації у соціальних мережах може бути усвідомлення ними двох фактів:

- володіння українською літературною мовою стає важливим професійним показником освіченої людини, тому, опановуючи мову, учень/студент робить інвестиції у своє майбутнє. Неможливо у повсякденному спілкуванні вживати мову-суржик, сленг і сподіватися, що за нагоди, у розмові з учителем, можливо заговорити грамотною мовою;

- високий рівень Інтернет-мовлення й писемної грамотності в міжособистісній комунікації в електронних соціальних мережах суб'єктів навчально-виховного 
процесу $\epsilon$ важливими аспектами підвищення рівня медіакультури, медіаінформаційної компетентності особистості та необхідними вимогами сучасного інформаційного суспільства для здійснення проектно-орієнтованої, навчально-пізнавальної й ефективної інноваційної діяльності в освітній практиці. Подальшим перспективним напрямом вважаємо дослідження широкого спектру проблем медіакультури особистості, зокрема медіаінформаційної компетентності учителів у сучасному інформаційному суспільстві.

\section{СПИСОК ВИКОРИСТАНИХ ДЖЕРЕЛ}

[1] О. Е. Коневщинська, С. Г. Литвинова, "Електронні соціальні мережі як складник сучасних соціальних медіа", Інформаційні технологї $i$ засоби навчання, т. 55, № 5, с. 42-54, 2016. [Електронний ресурс]. Доступно: http://journal.iitta.gov.ua/index.php/itlt/article/view/1500. Дата звернення: Квіт. 30, 2017.

[2] О.Т. Баришполець, "Український словник медіакультури". Київ, Україна: Міненіум, 2014.

[3] Енциклопедія освіти / Акад. пед.. наук України ; головний ред.. В.Г.Кремень. К. : Юрінком Інтер, 2008, с. 513-514

[4] О. Е. Коневщинська, "Формування медіакомпетентності старшокласників засобами електронних соціальних мереж", Звітна наук.-конф. Інституту інформаційних технологій $і$ засобів навчання НАПН Украӥни, Київ, 2016. [Електронний ресурс]. Доступно: http://lib.iitta.gov.ua/166216/1/Tezy_IITZN_2016.4.PDF. Дата звернення: Трав. 18, 2017.

[5] О. В. Овчарук та ін., Формування інформаційно-комунікаційних компетентностей у контексті євроінтеграџійних процесів створення інформаційного освітнього простору. Київ, Україна: Атіка, 2014.

[6] О. М. Немеш, "Вплив спілкування в соціальних мережах на розвиток особистості підлітка" Проблеми сучасної психологї: Збірник наукових праць К-ПНУ імені Івана Огієнка, Інституту психології імені Г. С.Костюка НАПН України, Кам'янець-подільський: Аксіома, Вип.26, 2014, с. 442-456.

[7] В. В. Каптюрова, "Сленг соціальних мереж та мікроблогів", Лінгвістика ХХІ століття: нові дослідження і перспективи". Київ. Україна. 2012, с. 134-140.

[8] В. В. Каптюрова "Комунікативні стратегії користувачів соціальних мереж та мікроблогів" Лінгвістика ХХІ століття: нові дослідження і перспективи. Київ. Україна, 2013, с. 104-111.

[9] Ю. А. Маковецька-Гудзь, "Українська мова в соціальних мережах" НТУУ "КПІ"[Електронний pecypc].Доступно: http://philology.knu.ua/files/library/movni_i_konceptualni/47-1/77.pdf Дата звернення: серпень, 2017

[10] Н. М. Шульська, Н.М. Матвійчук, "Соціальні мережі як ефективне середовище викладацькостудентської комунікації в навчальному процесі," Інформаційні технології і засоби навчання, т. 58, №2, с. 155-168, 2017, [Електронний ресурс]. Доступно: http://journal.iitta.gov.ua/index.php/itlt/article/view/1590. Дата звернення: Квіт. 30, 2017.

[11] С. Г. Чемеркін, Українська мова в Інтернеті: позамовні та внутрішньоструктурні процеси, Київ, Україна, 2009. с. 56-57.

Матеріал надійшов до редакиії 12.09.2017p.

\section{ПРОБЛЕМА ИНТЕРНЕТ-РЕЧИ СТАРШЕКЛАССНИКОВ В ЭЛЕКТРОННЫХ СОЦИАЛЬНЫХ СЕТЯХ}

\section{Коневщинская Ольга Эммануиловна}

кандидат педагогических наук, старший научный сотрудник, ученый секретарь Институт информационных технологий и средств обучения НАПН Украины г. Киев, Украина ORCID 0000-0003-4125-8764

ok17188vk@ukr.net 


\begin{abstract}
Аннотация. В статье исследована проблема интернет-речи старшеклассников во время межличностной коммуникации в электронных социальных сетях. Обоснована актуальность, осуществлен системный анализ психолого-педагогической и учебно-методической литературы по проблеме исследования. Рассмотрены внешнее письменное говорение как важный фактор коммуникационной культуры личности. Определено, что высокий уровень говорения как учеников, так и учителей в процессе межличностной коммуникации в электронных социальных сетях являются важными аспектами повышения уровня медиакультуры, медиаинформационного компетентности личности и необходимыми требованиями информационного общества для осуществления эффективной проектноориентированной, учебно-познавательной и инновационной деятельности в образовательной практике.
\end{abstract}

Ключевые слова: Интернет-речь; межличностная коммуникация; социальные сети.

\title{
PROBLEM OF INTERNET COMMUNICATION OF UPPER SECONDARY SCHOOL PUPILS IN ELECTRONIC SOCIAL NETWORKS
}

\author{
Olga E. Konevshchynska \\ Ph.D. (in Pedagogics), Senior Researcher, Scientific Secretary \\ Institute of Information Technologies and Learning Tools of NAES of Ukraine, Kyiv, Ukraine \\ ORCID ID 0000-0003-4125-8764 \\ ok17188vk@ukr.net
}

\begin{abstract}
The article deals with the problem of Internet communication of upper secondary school pupils during interpersonal communication in electronic social networks. The actuality is proved, the system analysis of the psychological and pedagogical, educational-methodical literature of the researched problem is carried out. External written Internet speaking is considered as an important factor in the communication culture of the individual. It has been determined that high level of Internet communication of both students and teachers in the process of interpersonal communication in electronic social networks are important aspects of raising the level of media culture, media information competence of the individual. Also, these ones are necessary requirements of the information society to fulfill project-oriented, educational-cognitive and effective innovative activity in educational practice.
\end{abstract}

Keywords: Internet communication; Interpersonal communication; social networks.

\section{REFERENCES (TRANSLATED AND TRANSLITERATED)}

[1] O. E. Konevshchynska, S. G. Litvinova, Electronic social networks as a component of modern social media, Information technology and training, vol. 55, number 5, p. 42-54, 2016. [Online]. Available: http://journal.iitta.gov.ua/index.php/itlt/article/view/1500. Accessed on: Apr. 30, 2017. (in Ukrainian)

[2] O. T Baryshpolets Dictionary Ukrainian media culture. Kyiv, Ukraine: Minenium 2014. (in Ukrainian)

[3] Encyclopedia of Education / Acad. ped. of Sciences of Ukraine; chief ed. V.G.Kremen. K.: Yurinkom Inter, 2008, p. 513-514 (in Ukrainian)

[4] O. E. Konevshchytska, "Formation of Media Competence of Senior Students by Means of Electronic Social Networks", Scientific-Research Conference. Institute of Information Technologies and Training Facilities of the National Academy of Sciences of Ukraine, Kyiv, 2016. [online]. Available at: http://lib.iitta.gov.ua/166216/1/Tezy_IITZN_2016.4.PDF. Accessed on: Herb. 18, 2017. (in Ukrainian)

[5] O. V. Ovcharuk, etc., Formation of information and communication competencies in the context of European integration processes of creation of informational educational space. Kyiv, Ukraine: Atika, 2014. (in Ukrainian)

[6] O.H. Nemesh, "The Influence of Social Networking on the Development of the Teen Personality" Problems of Contemporary Psychology: Collection of Scientific Papers of Ivan Ogienko K-PNU, GSKostiuk Institute of Psychology, National Academy of Sciences of Ukraine, Kamyanets-Podilsky: Axioma, 2014, Vip.26, p.442-456. (in Ukrainian)

[7] V. V. Kaptyurova, Slang social networking and micro-blogging Linguistics XXI century: new research and perspectives. Kiev. Ukraine. 2012, p.134-140. (in Ukrainian) 
[8] V. V. Kaptyurova, Communication Strategies users of social networking and micro-blogging / Linguistics XXI century: new research and perspectives. Kiev. Ukraine. 2013. p.104-111. (in Ukrainian)

[9] Yu.A. Makovetska-Gudz, " Ukrainian Language in Social Networks" NTUU "KPI" Kiev. Ukraine. [online]. Available at: http://philology.knu.ua/files/library/movni_i_konceptualni/47-1/77.pdf Accessed on: August 2017 (in Ukrainian).

[10] N. M. Shulska, N. M. Matviichuk, Social networking as an effective medium of communication facultystudent in the learning process, Information technology and training, vol. 58, №2, p. 155-168, 2017 [Online]. Available: http://journal.iitta.gov.ua/index.php/itlt/article/view/1590. Accessed on: Apr. 30, 2017. (in Ukrainian)

[11] S.G. Chemerkin, Ukrainian on the Internet: extra-curricular and inter-structural processes, Kiev. Ukraine. 2009, p 56-57 (in Ukrainian). 